\title{
Analisis investasi sektor industri manufaktur, pengaruhnya terhadap pertumbuhan ekonomi dan penyerapan tenaga kerja di Indonesia
}

\author{
Irma Mar'atus Sholihah; Syaparuddin; Nurhayani*
}

\author{
Prodi Ekonomi Pembangunan, Fakultas Ekonomi dan Bisnis, Universitas Jambi \\ *E-mail korespondensi:nurhayani@unja.ac.id
}

\begin{abstract}
This resource conducted to analyze the factors that influence investment in the manufacturing industry in Indonesia, analyze influence of investment the manufacturing industry to economic growth and employment of manufacturing in Indonesia. This resource uses approach of simultaneous with two stage square method (2SLS). The result shows that investment in the manufacturing industry simultaneously influenced by interest rate, exchange rate, and manufacturing industry employment. That infestation used as one of component of economic development an area because through investment, production capacity can be improved, then can be improved the output, which will eventually increase the economic growth and the manufacturing industry employment in Indonesia.
\end{abstract}

Keywords: Investment, Economic Growth, Employment, Approach of Simultaneous With Two Stage Square Method

\begin{abstract}
Abstrak
Penelitian ini bertujuan menganalisis faktor-faktor yang mempengaruhi investasi sektor industri manufaktur di Indonesia, menganalisis pengaruh investasi sektor industri manufaktur terhadap pertumbuhan ekonomi dan penyerapan tenaga kerja sektor industri manufaktur di Indonesia. Penelitan ini menggunakan model persamaan simultan dengan metode two stage least squre (2SLS). Hasil penelitian menunjukkan investasi industri manufaktur secara simultan dipengaruhi oleh suku bunga (SB), nilai tukar (NT) dan penyerapan tenaga kerja industri manufaktur (PTK). Investasi tersebut digunakan sebagai salah satu komponen pembangunan perekonomian suatu wilayah karena melalui investasi, kapasitas produksi dapat ditingkatkan yang kemudian mampu meningkatkan output, yang akhirnya juga akan meningkatkan pertumbuhan ekonomi dan penyerapan tenaga kerja sektor industri manufaktur di Indonesia.
\end{abstract}

Kata Kunci : Investasi, Pertumbuhan Ekonomi, Penyerapan Tenaga Kerja, Model Persamaan Simultan, Two Stage Least Square (2SLS).

\section{PENDAHULUAN}

Dalam proses pembangunan, Sektor industri dijadikan sebagai prioritas pembangunan yang diharapkan mempunyai peranan sebagai leading sector atau sektor pemimpin bagi pembangunan sektor-sektor lainnya (Arsyad, 2010:442). Leading sector maksudnya adalah dengan pembangunan industri maka memacu dan mengangkat pembangunan sektor-sektor lainnya seperti sektor pertanian dan sektor jasa. Menurut Lewis dalam Todaro (2006:132), pengaruh pertumbuhan ekonomi terhadap penyerapan tenaga kerja dimulai dari investasi di sektor industri, dan akumulasi modal secara keseluruhan di sektor modern akan menimbulkan perluasan output pada sektor modern 
tersebut. Pengalihan tenaga kerja dari sektor pertanian ke sektor modern (industri) selanjutnya akan meningkatkan pertumbuhan output dan peningkatan penyerapan tenaga kerja di sektor modern.

Menurut Arsyad (2004), dalam teori Solow-Swan , capital output ratio (COR) memiliki sifat yang dinamis, artinya dalam menghasilkan tingkat output tertentu dibutuhkan kombinasi yang seimbang antara kapital dan tenaga kerja. Jika penggunaan kapital tinggi maka penggunaan tenaga kerja akan rendah, sebaliknya jika penggunaan kapital rendah maka penggunaan tenaga kerja akan tinggi.

Industri merupakan sektor utama yang menyerap banyak investor domestik. Walaupun investasi sektor industri manufaktur mengalami fluktuasi sejak tahun 2001 sampai 2015. Akan tetapi jumlahnya cenderung meningkat setiap tahunnya, pada tahun 2001 sebesar Rp.44.387 Milyar, tahun 2003 sebesar RP.40.443 Milyar, tahun 2006 sebesar Rp.13.152 Milyar, tahun 2009 sebesar Rp. 194.343 Milyar, tahun 2012 sebesar Rp.498891 Milyar dan tahun 2015 sebesar Rp. 890.453 Milyar. Untuk jumlah yang paling rendah dari Investasi sektor industri manufaktur di Indonesia pada tahun 2001 hingga 2015 adalah pada tahun 2006, yaitu sebesar Rp. 13.152 Milyar dan jumlah terbesar pada tahun 2015 sebesar Rp. 890.453 Milyar yang pada tahun 2014 sebesar Rp. 590.347 Milyar (Badan Pusat Statistik dan BKPM).

Investasi menjadi penting bagi pertumbuhan ekonomi terkait dengan kontribusi yang diberikannya. Kontribusi investasi terhadap pertumbuhan ekonomi bisa dilihat dari sisi permintaan dan penawaran. Dari sisi permintaan, peningkatan investasi menstimulasi petumbuhan ekonomi dengan menciptakan permintaan yang efektif. Berdasarkan sisi penawaran, peningkatan investasi merangsang pertumbuhan ekonomi dengan menciptakan lebih banyak cadangan modal yang kemudian berkembang dalam bentuk peningkatan kapasitas produksi.

Investasi sektor industri manufaktur yang cenderung meningkat setiap tahunnya, berbeda dengan pertumbuhan ekonomi dan penyerapan tenaga kerja yang berfluktuasi dan hanya mengalami sedikit peningkatan. Bahkan untuk penyerapan tenaga kerja dari tahun 2001 hingga 2015 masih dibawah 20\%. Bila dilihat gambar 1.1 penyerapan tenaga kerja sektor industri manufaktur pada tahun 2001 sebesar 13,2\%, tahun 2005 sebesar 12,7 \%, tahun 2010 sebesar 12,8\%, tahun 2013 sebesar 13,79\%, tahun 2014 sebesar 13,63\% dan tahun 2015 sebesar 13,87\%.

Untuk perkembangan penyerapan kerja paling rendah pada tahun 2004 sebesar $11,8 \%$ dan paling tinggi tahun 2012 sebesar 14,35\%. Sedangkan pertumbuhan ekonomi tahun 2001 sebesar 3,64\%, tahun 2005 sebesar 5,69\%, tahun 2010 sebesar 6,22\%, tahun 2014 sebesar 5,02\% dan tahun 2015 sebesar 4,79\%. Pertumbuhan ekonomi paling rendah pada tahun 2001 sebesar 3,64\% dan paling tinggi tahun 2011 sebesar 6,49\%

Berdasarkan latar belakang tersebut diperlukan sebuah kajian mengenai investasi sektor industri manufaktur, pengaruhnya terhadap pertumbuhan ekonomi dan penyerapan tenaga kerja Di Indonesia”.

\section{TINJAUAN PUSTAKA}

\section{Teori Pertumbuhan Inklusif}

Teori pertumbuhan inklusif digunakan sebagai kerangka berpikir untuk mengidentifikasi penghambat pertumbuhan dari sisi penyediaan lapangan kerja yang berasal dari pembentukan investasi. Sektor swasta di suatu daerah memiliki kelebihan tabungan yang dapat dialokasikan untuk berinvestasi. Maka investasi tersebut cenderung digunakan untuk memperluas pasar dengan menambah output dan memperkerjakan lebih banyak pekerja. Diagnosa pertumbuhan ini bekerja dengan cara menganalisa komponen pertumbuhan yang paling berpengaruh dan menemukan faktor apa saja yang dapat mempengaruhi komponen tersebut. Menurut Haussman, et.al 12 
(2005), komponen yang menghambat pertumbuhan di sebuah wilayah adalah iklim investasi dan faktor apa saja yang akan mempengaruhi tingkat investasi tersebut.

\section{Teori Pertumbuhan Harrord-Domar}

Menurut teori Harrord-Domar, pembentukan modal merupakan faktor penting yang menentukan pertumbuhan ekonomi. Pembentukan modal tersebut dapat diperoleh melalui proses akumulasi tabungan. Dalam teori Harrord-Domar pembentukan modal tidak hanya dipandang sebagai pengeluaran yang akan menambah kemampuan suatu perekonomian untuk menghasilkan barang dan jasa, tetapi juga akan meningkatkan permintaan efektif masyarakat.

Teori ini menunjukan sebuah kenyataan yang cenderung diabaikan oleh Keynes yaitu pada suatu periode tertentu dilakukan sejumlah pembentukan modal, maka pada masa berikutnya perekonomian tersebut akan mempunyai kemampuan yang lebih besar dalam menghasilkan barang dan jasa. Namun, teori ini juga menganggap bahwa kenaikan kapasitas produksi dan pendapatan nasional ditentukan oleh kenaikan pengeluaran masyarakat. Dengan demikian, meskipun kapasitas produksi bertambah, pendapatan nasional baru akan mengalami kenaikan hanya jika terjadi kenaikan pengeluaran masyarakat (Arsyad, 2010:83).

\section{Teori Pertumbuhan Ekonomi Solow-Swan}

Model pertumbuhan Solow dirancang untuk menunjukkan bagaimana pertumbuhan persediaan modal, pertumbuhan angkatan kerja, dan kemajuan teknologi berinteraksi dalam perekonomian, serta bagaimana pengaruhnya terhadap output barang dan jasa suatu negara secara keseluruhan (Mankiw, 2006).

Menurut Arsyad (2004), dalam teori Solow-Swan ini, capital output ratio (COR) memiliki sifat yang dinamis, artinya dalam menghasilkan tingkat output tertentu dibutuhkan kombinasi yang seimbang antara kapital dan tenaga kerja. Jika penggunaan kapital tinggi maka penggunaan tenaga kerja akan rendah, sebaliknya jika penggunaan kapital rendah maka penggunaan tenaga kerja akan tinggi. Pokok pemikiran lainya adalah dalam fungsi produksinya adanya teknologi yang teragumentasi pada faktorfaktor produksi seperti kapital dan labor, sebagaimana terlihat pada model di bawah ini:

$\mathrm{Y}=\mathrm{F}(\mathrm{K}, \mathrm{AL})$

$\mathrm{Y}=\mathrm{F}(\mathrm{AK}, \mathrm{L})$

\section{Teori Pertumbuhan Industri Kaldorian}

Teori Kaldor menganggap bahwa sektor industri manufaktur merupakan mesin pertumbuhan bagi sebuah wilayah dalam meningkatkan pertumbuhan sektor-sektor lain sekaligus meningkatkan pertumbuhan ekonomi. Teori pertumbuhan Kaldor. Dalam penelitian Dewi (2010), teori ini terdapat tiga aspek industri yang disorot. Pertama, Pertumbuhan GDP memiliki hubungan positif terhadap pertumbuhan sektor industri pengolahan. Kedua, produktivitas tenaga kerja sektor industri pengolahan memiliki hubungan positif dengan pertumbuhan sektor industri pengolahan itu sendiri. Dalam hal ini sektor industri pengolahan dianggap dapat menghasilkan increasing return to scale (skala pengembalian yang meningkat). Skala tersebut dapat tercipta apabila sektor ini melakukan akumulasi modal dan inovasi teknologi. Dalam hal ini learning by doing sangat penting untuk mempertahankan kondisi mapan yang bersifat jangka panjang pada sektor tersebut. Ketiga, pertumbuhan sektor non-industri pengolahan memiliki hubungan positif dengan pertumbuhan sektor industri pengolahan.Hal ini dilatarbelakangi oleh kecenderungan sektor non-industri pengolahan yang mengarah pada diminishing return to scale.

Teori pertumbuhan industri Kaldorian kedua menyebutkan bahwa increasing return to scale hanya dapat tercipta dengan adanya akumulasi modal dan kemajuan teknologi. Faktor investasi menjadi sorotan tersendiri dalam pengembangan teori, 
dikarenakan investasi mampu memberikan manufacturing insentive yang dapat mempercepat pertumbuhan sektor. Dibutuhkan tingkat investasi yang tinggi untuk dapat memperbaharui mekanisasi teknik dari produksi.

Menurut Djojohadikusumo (1994), mekanisasi teknik produksi dapat diwujudkan dengan penambahan modal per tenaga kerja. Pertumbuhan sektor industri pengolahan dapat terlihat dari produktifitas pekerja dan rasio modal terhadap tenaga kerja. Hal ini memperlihatkan bahwa faktor investasi sebagai bentuk akumulasi modal sangat penting dalam peningkatan produktifitas dan pertumbuhan sektor industri pengolahan.

\section{METODE PENELITIAN}

\section{Jenis dan Sumber Data}

Jenis data yang digunakan dalam penelitian ini adalah data sekunder runtun waktu (time series) selama tahun 2001-2015, yang mencakup data suku bunga, nilai tukar rupiah, konsumsi rumah tangga, impor bahan baku industri manufaktur, ekspor hasil industri manufaktur, pertumbuhan ekonomi industri manufaktur dan penyerapan tenaga kerja manufaktur. Sumber data utama adalah Badan Pusat Statistik, Bank Indonesia dan Kementerian Perindustrian Republik Indonesia.

\section{Metode Analisis Data}

Analisis dalam penelitian ini menggunakan Model Persamaan Simultan (simultaneous Equations Models) oleh karena variabel-variabel yang diteliti saling berkaitan satu sama lain. Untuk pengujian digunakan model ekonometrika persamaan simultan melalui penyusunan model investasi industri manufaktur, pertumbuhan ekonomi industri manufaktur, dan penyerapan tenaga kerja industri manufaktur.

Model persamaan secara bersama-sama bergantung (jointly dependent) variabelnya dapat dituliskan sebagaimana bentuk persamaan dalam penelitian ini yang secara matematis dirumuskan sebagai berikut:

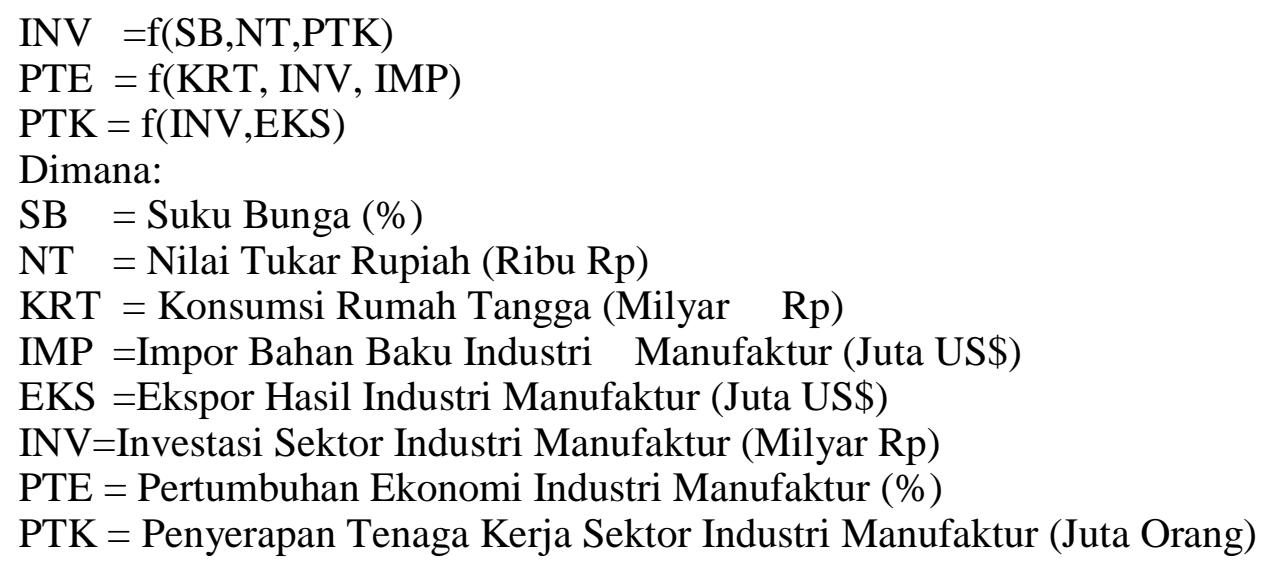

Sehingga model persamaan simultan yang akan dianalisis dapat dirumuskan sebagai berikut :

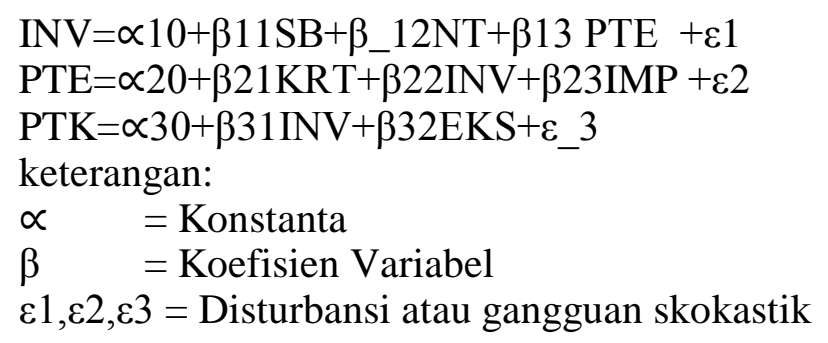

\section{HASIL DAN PEMBAHASAN}




\section{Investasi Industri Manufaktur di Indonesia}

Sektor Industri masih menjadi primadona investasi dalam negeri dengan kontribusi investasi sektor industri terhadap PMDN selama periode 2001-2015 tertinggi dari sektor yang lain. Hal ini disebabkan Industri menjadi lapangan usaha yang akan terus berkembang seiring kemajuan teknologi dan peningkatan Sumber Daya Manusia (SDM). Sektor industri menjadi tujuan utama bagi para pemodal untuk menanamkan modalnya. Sekalipun kontibusi investasi sektor tersebut berfluktuasi namun setiap tahun masih tetap menempati urutan pertama. Oleh karena itu sebagian besar dana pembangunan oleh pemerintah dialokasikan kepada sektor tersebut.

Penanaman Modal Dalam Negeri (PMDN) di Indonesia mengalami fluktuasi sejak tahun 2001 sampai 2015. Akan tetapi jumlahnya cenderung meningkat setiap tahunnya, pada tahun 2001 sebesar Rp.44.387 Milyar, tahun 2003 sebesar RP.40.443 Milyar, tahun 2006 sebesar Rp.13.152 Milyar, tahun 2009 sebesar Rp. 194.343 Milyar, tahun 2012 sebesar Rp.498.891 Milyar dan tahun 2015 sebesar Rp. 890.453 Milyar. Untuk jumlah yang paling rendah dari Investasi sektor industri manufaktur di Indonesia pada tahun 2001 hingga 2015 adalah pada tahun 2006, yaitu sebesar Rp. 13.152 Milyar dan jumlah terbesar pada tahun 2015 sebesar Rp. 890.453 Milyar yang pada tahun 2014 sebesar Rp. 590.347 Milyar. perkembangan investasi industri manufaktur di Indonesia selalu naik dan turun setiap tahunnya. Perkembangan tertinggi pada tahun 2007 dan terendah tahun 2010.

\section{Pertumbuhan Ekonomi Industri Manufaktur di Indonesia}

Secara umum, dari tahun 2001-2015 kinerja perekonomian Indonesia menunjukan pertumbuhan yang melambat. Hal ini tidak terlepas dari kondisi internal dimana masih tingginya resiko dan ketidakpastian yang berkelanjutan berbagai permasalahan dalam negeri yang terkait dengan restrukturisasi utang. Hal ini mengakibatkan menurunnya kepercayaan dunia usaha untuk melakukan kegiatan produksi dan investasi, yang pada akhirnya menghambat pertumbuhan ekonomi yang tercermin dari pertumbuhan ekonomi yang turun.

Sektor industri merupakan sektor yang sangat berperan dalam pembangunan ekonomi karena dapat meningkatkan pertumbuhan ekonomi. Sektor industri juga berperan sebagai faktor produktif dalam memaksimalkanpembangunan.perkembangan sektor industri tidak hanya ditandai dengan semakin meningkatnya volume produksi, tetapi dengan semakin beragamnya jenis produk yang dihasilkan.

Salah satu tolak ukur keberhasilan pembangunan di bidang ekonomi yang diperlukan untuk evaluasi dan perencanaan ekonomi makro, biasanya dilihat dari pertumbuhan angka Produk Domestik Regional Bruto (PDB), baik atas harga berlaku maupun harga konstan. Dengan melihat angka PDB dapat memberikan gambaran pelaksanaan pembangunan yang telah dicapai. Dalam lima belas tahun terakhir, pertumbuhan ekonomi industri manufaktur di Indonesia berfluktuasi tetapi cenderung tumbuh melambat. Dalam periode 2001-2005 selalu mengalami peningkatan meskipun tidak terlalu tinggi. Pertumbuhan ekonomi pada tahun 2005 tercatat sebesar 4,60\%, Pada tahun 2007, perekonomian Indonesia dibayangi oleh gejolak eksternal sebagai efek dari terjadinya krisis di Amerika Serikat. Untungnya perekonomian Indonesia masih dapat mencatat prestasi yang cukup baik, hal ini tercermin pada peningkatan pertumbuhan ekonomi.

Pada tahun 2011 mengalami pertumbuhan sebesar 6,14\% lebih tinggi bila dibanding dengan tahun 2010 yang sebesar 4,74\% dan tahun 2009 yang sebesar $2.21 \%$. Pada tahun 2012, perekonomian Indonesia sektor industri manufaktur kembali mengalami penurunan sebesar 5,52\% dan hingga tahun 2013 melambat di besaran 4,37\%. Lambannya pertumbuhan ekonomi tahun 2013 disebabkan ketidakpastian ekonomi global dan adanya isu finansial seperti defisit transaksi berjalan, inflasi yang 
tinggi (kenaikan harga BBM bersubsidi pada Juni 2013) dan nilai tukar rupiah yang melemah. Kondisi penurunan tersebut berlanjut hingga pada tahun 2015 menjadi 4,25\%. Dari penjelasan diatas maka grafiknya dapat dilihat pada gambar 4.3. Berdasarkan gambar 4.3 terlihat bahwa perkembangan investasi industri manufaktur di Indonesia selalu naik dan turun setiap tahunnya. Perkembangan tertinggi pada tahun 2004 dan terendah tahun 2009.

\section{Penyerapan Tenaga Kerja Industri Manufaktur di Indonesia}

Penyerapan tenaga kerja merupakan jumlah riil dari tenaga kerja yang dikerjakan dalam unit usaha. Sektor pertanian masih mendominasi struktur tenaga kerja di Indonesia karena merupakan sektor yang paling banyak menyerap tenaga kerja. Pada tahun 2003 jumlah penduduk yang bekerja di sektor pertanian, kehutanan, perburuan, dan perikanan mencapai 46,40\% dari total keseluruhan penduduk yang bekerja.

Namun, sejalan dengan perkembangan zaman sektor ini mulai ditinggalkan dan beralih ke sektor lain. Hal ini terlihat perkembangannya selama periode 2001-2015 dimana persentase jumlah penduduk yang bekerja pada sektor ini mengalami penurunan setiap tahunnya. dan pada tahun 2015 tercatat sebesar 33,20\% yang pada tahun sebelumnya yaitu tahun 2014 sebesar 34,00\%.

Dari tahun ke tahun penyerapan tenaga kerja sektor industri semakin berfluktuasi. Pada tahun 2001 penyerapan tenaga kerja sektor industri sebesar 12.086.122 orang dari tenaga kerja total yaitu 90.807 .417 orang, pada tahun 2002 mengalami kenaikan sebesar 12.109.997 orang atau 0,19\%, pada tahun berikutnya mengalami kenaikan hingga pada tahun 2012 sebesar 15.367.242 orang atau 5,68\%, kemudian kembali berfluktuasi hingga pada tahun 2015 sebesar 15.255.099 atau 0,003 yang sebelumnya 15.254.674 orang yaitu pada tahun 2014 .

Perkembangan penyerapan tenaga kerja industri manufaktur tertinggi yaitu pada tahun 2010 sebesar 7,67\% atau 13.824.251 orang, yang tahun 2009 sebesar 2,31\% atau 12.839.800 orang. Sedangkan penyerapan tenaga kerja terendah pada tahun 2003 sebesar $-5,07 \%$ atau 11.495 .887 orang yang pada tahun sebelumnya yaitu 2002 perkembangannya sebesar $0,19 \%$ atau 12.109 .997 orang.

\section{Estimasi Persamaan Simultan}

\section{Uji Identifikasi}

Identifikasi diperlukan untuk mengetahui bagaimana cara menyelesaikan sistem persamaan simultan yang ada atau apakah suatu sitem persamaan simultan ada penyelesaiannya atau tidak.

Ada tiga masalah identifikasi pada persamaan simultan, dimana dari masingmasing permasalahan identifikasi tersebut kita dapat mengetahui metode apa yang tepat untuk menyelesaikan suatu sistem persamaan simultan yang kita temui suatu persamaan simultan dapat diidentifikasi atau dapat diuji dapat dibuktikan dengan metode pengujian Kondisi order yang didasarkan atas kaidah perhitungan variabel-variabel yang dimasukkan kedalam dan dikeluarkan dari suatu persamaan tertentu. Dari model struktural yang telah disusun pada persamaan investasi sektor industri manufaktur (INV), pertumbuhan ekonomi sektor industri manufaktur (PTE), penyerapan tenaga kerja sektor industri manufaktur (PTK)

Berdasarkan kondisi order, persamaan dalam model structural yang diformulasikan tiga persamaan yaitu INV, PTE dan PTK dapat diidentifikasikan secara berlebih (artinya overidentified) seperti pada tabel berikut ini: 
Tabel 1. Hasil Pengujian Kondisi Order

\begin{tabular}{lccl}
\hline Persamaan Struktural & (K-k) & (m-1) & Kondisi Order \\
\hline $\begin{array}{l}\text { Investasi Sektor Industri } \\
\text { Manufaktur }\end{array}$ & 3 & 1 & Overidentified \\
$\begin{array}{l}\text { Pertmbuhan Industri } \\
\text { Manufaktur }\end{array}$ & 3 & 1 & Overidentified \\
$\begin{array}{l}\text { Penyerapan Tenaga Kerja } \\
\text { Industri Manufaktur }\end{array}$ & 4 & 1 & Overidentified \\
\hline
\end{tabular}

Berdasarkan Tabel 1, untuk dapat menghasilkan nilai parameter persamaan simultan yang tepat maka digunakan metode kuadrat terkecil dua tahap (Two Stage Least Square/2SLS).

\section{Uji Simultanitas}

Kondisi simultanitas pada suatu system persamaan simultan perlu dilakukan uji simultanitas untuk menentukan apakah terjadi bias simultanitas ataukah tidak. Jika tidak ada persamaan simultan atau masalah simultanitas, estimator OLS akan menghasilkan estimator yang konsisten dan efisien. Dilain pihak, jika ada simultanitas estimator OLS tidak konsisten. Untuk mengetahui secara konkret situasi ini, kita dpat menggunakan uji spesifikasi Hausman. Keputusan dalam uji spesifikasi Hausman ini adalah membandingkan antara nilai $\mathrm{t}$ statistic dan residual yang dimasukkan dalam persamaan dengan nilai t-tabel. Jika nilai t-statistik lebih besar dari t-tabel maka persamaan tersebut mengalami masalah simultan.

Berdasarkan ketentuan uji spesifikasi Hausman maka didapatkan diregresikan persamaan reduce form hasil regresi persamaan PTK dan didapatkan residualnya dan diregresikan ke persamaan PTE. Kemudian didapatkan residual PTE dan di regresikan kembali ke persamaan INV. Sehingga hasil uji simultanitas didapatkan sebagai berikut :

Tabel 2.Hasil Uji Simultanitas

\begin{tabular}{|c|c|c|c|}
\hline Persamaan Struktural & t-statistik residual & Prob. & Ket. \\
\hline $\begin{array}{l}\text { Pertumbuhan Ekonomi } \\
\text { Industri Manufaktur }\end{array}$ & -1.351436 & 0.2063 & Bias simultan \\
\hline $\begin{array}{l}\text { Investasi Sektor Industri } \\
\text { Manufaktur }\end{array}$ & 1.400190 & 0.1917 & Bias simultan \\
\hline $\begin{array}{l}\text { Pertumbuhan Ekonomi } \\
\text { Industri Manufaktur }\end{array}$ & $2.526794 *$ & 0.0300 & Simultan \\
\hline $\begin{array}{l}\text { Penyerapan Tenaga Kerja } \\
\text { Industri Manufaktur }\end{array}$ & -0.444937 & 0.6650 & Bias Simultan \\
\hline
\end{tabular}

Catatan : * Signifikan pada a critical value $5 \%$

** Signifikan pada $\alpha$ critical value $10 \%$

*** Signifikan pada $\alpha$ critical value $25 \%$

Pada tabel hasil uji simultanitas dapat dilihat bahwa pada persamaan PTE Industri manufaktur (hasil regresi dengan residual PTK) nilai t statistic sebesar 1.35 dan nilai probababilitanya sebesar 0.2063 , Jika nilai t-statistik>t-tabel maka model tersebut dapat disimpulkan mengalami masalah simultan karena 1.351436 lebih besar dari t-tabel pada taraf nyata sebesar $10 \%$.

Pada persamaan INV (hasil regesi dengan residual PTE) nilai t statistik nya sebesar adalah 1.400190 dan nilai probababilitanya sebesar 0.1917. maka didapatkan 
nilai t-statistik yang lebih besar dari t-tabel pada taraf nyata $10 \%$, maka model tersebut dapat disimpulkan mengalami masalah simultan

\section{Uji Eksogenitas}

Keputusan dalam uji eksogenitas ini adalah berdasarkan pada nilai F-statistik yang dibandingkan nilai F-tabel. Dengan menggunakan uji F kita menguji hipotesis bahwa Fstatistik pada persamaan sama dengan 0. Jika hipotesis ini ditolak maka persamaan dapat dianggap endogen, tetapi jika tidak ditolak, maka tidak dapat dianggap sebagai endogen. Uji Eksogenitas ini hasil regresi antara persamaan struktural dan fitted value variabel endogen.

Tabel 3.Hasil Uji Eksogenitas

\begin{tabular}{lccc}
\hline \multicolumn{1}{c}{ Persamaan Struktural } & F-statistik & Prob. & Ket. \\
\hline $\begin{array}{l}\text { Investasi Sektor Industri } \\
\text { Manufaktur }\end{array}$ & 2.836961 & 0.0825 & Eksogen \\
$\begin{array}{l}\text { Pertumbuhan Ekonomi } \\
\text { Industri Manufaktur }\end{array}$ & 2.699653 & 0.0923 & Eksogen \\
$\begin{array}{l}\text { Penyerapan Tenaga Kerja } \\
\text { Industri Manufaktur }\end{array}$ & 45.83690 & 0,0000 & Endogen \\
\hline
\end{tabular}

Hasil uji eksogenitas pada tabel bahwa pada persamaan INV memiliki F-statistik 2.836961 dengan nilai probabilita 0,0825 ini menunjukan bahwa persamaan INV dapat dianggap eksogen, persamaan PTE memiliki F-statistik sebesar 2.699653 dengan nilai signifikan 0,0923 ini membuktikan bahwa persamaan PTE bersifat eksogen dan persamaan PTK memiliki F-statistik sebesar 45.83690 dengan nilai signifikan 0,0000 berarti persamaan PTK bersifat endogen. Berdasarkan hasil uji tersebut terlihat bahwa ketiga variable dalam persamaan diatas satu bersifat endogen

\section{Hasil Estimasi Persamaan Simultan}

Penelitian ini menggunakan metode Two Stage Least Square (2SLS) yang akan memperlihatkan hubungan antara rumusan masalah persamaan investasi industri manufaktur, pertumbuhan ekonomi industri manufaktur, dan penyerapan tenaga kerja industri manufaktur. Setelah dilakukan pengolahan data maka didapatkan hasil estimasi dan hasil uji untuk persamaan investasi industri manufaktur, pertumbuhan ekonomi industri manufaktur, dan penyerapan tenaga kerja industri manufaktur sebagai berikut :

$\underline{\text { Hasil Estimasi Persamaan Investasi Industri Manufaktur }}$

Berdasarkan hipotesis yang telah dilakukan dapat dikatakan investasi industri manufaktur dipengaruhi oleh SB, NT dan pertumbuhan ekonomi. Ketiga variabel tersebut memiliki pengaruh signifikan terhadap investasi sektor industri manufaktur.

Tabel 4.Hasil Estimasi Persamaan Investasi Industri Manufaktur

\begin{tabular}{lllll}
\hline Variabel & Koefisien & t-statistik & Prob. & t-tabel $\alpha=5 \%$ \\
\hline C & -2033722. & -7.688244 & 0.0000 & 1,812 \\
SB & 9590.843 & 0.796592 & 0.4425 & 1,812 \\
NT & 69.79614 & $2.817651^{*}$ & 0.0167 & 1,812 \\
PTK & 0.118648 & $4.651423^{*}$ & 0.0007 & 1,812 \\
\hline R-square & $=0.87057$ & F-statistik & $=25.78146$ & \\
R-square Adj. & $=0.83527$ & Prob F-statistik $=0.000028$ & \\
\multicolumn{4}{l}{ Catatan $: *$ Signifikan pada $\alpha$ critical value 5\% }
\end{tabular}


Dari hasil regresi menunjukan nilai koefisien determinasi ( $\mathrm{R}$ square) sebesar 0,8706 yang berarti bahwa variabel dalam persamaan ini suku bunga, nilai tukar dan pertumbuhan ekonomi mempengaruhi perkembangan investasi sektor industri manufaktur sebesar $87,06 \%$ sedangkan sisanya $12,94 \%$ dijelaskan oleh variabel-variabel lain diluar model.

Hasil Estimasi Persamaan Pertumbuhan Ekonomi

Persamaan kedua yaitu persamaan PTE Industri Manufaktur, hasil estimasi dan hasil uji untuk persamaan ini seperti pada tabel berikut ini:

Tabel 5.Hasil Estimasi Persamaan PTE Industri Manufaktur

\begin{tabular}{ccccc}
\hline Variabel & Koefisien & t-statistik & Prob. & t-tabel $\alpha=5 \%$ \\
\hline C & 4.270797 & 6.276376 & 0.0001 & 1,812 \\
KRT & $1.68 \mathrm{E}-06$ & $2.358246^{*}$ & 0.0379 & 1,812 \\
INV & $-8.23 \mathrm{E}-06$ & $-2.370496^{*}$ & 0.0371 & 1,812 \\
IMP & -0.000337 & -1.096342 & 0.2964 & 1,812 \\
\hline R-square & $=0.27344$ & \multicolumn{2}{c}{ F-statistik } & $=2.036034$ \\
R-square Adj. & $=0.07529$ & \multicolumn{2}{c}{ Prob F-statistik $=0.167242$} \\
\hline
\end{tabular}

Catatan : * Signifikan pada $\alpha$ critical value $5 \%$

Regresi persamaan PTE Industri Manufaktur diatas menunjukan hasil nilai koefisien determinasi ( $\mathrm{R}$ square) sebesar 0,2734 yang berarti bahwa variabel dalam persamaan ini konsumsi rumah tangga, investasi industri manufaktur, dan impor bahan baku industri mempengaruhi perkembangan PTE Industri Manufaktur sebesar 27,34\% sedangkan sisanya 72,66\% dijelaskan oleh variabel-variabel lain diluar model.

\section{Hasil Estimasi Persamaan Penyerapan Tenaga Kerja}

Berikutnya Persamaan ketiga yaitu persamaan penyerapan tenaga kerja, hasil estimasi dan hasil uji untuk persamaan ini seperti pada tabel berikut ini:

Tabel 6.Hasil Estimasi Persamaan Penyerapan Tenaga Kerja Industri Manufaktur

\begin{tabular}{lllll}
\hline Variabel & Koefisien & t-statistik & Prob. & t-tabel $\alpha=5 \%$ \\
\hline $\mathrm{C}$ & 10253398 & 20.42275 & 0.0000 & 1,812 \\
$\mathrm{INV}$ & 2.229051 & $2.238701^{*}$ & 0.0449 & 1,812 \\
$\mathrm{EKS}$ & 29.02701 & $3.516016^{*}$ & 0.0043 & 1,812 \\
\hline R-square & $=0.89351$ & F-statistik & $=51.10150$ & \\
R-square Adj. & $=0.87576$ & Prob F-statistik $=0.000001$ & \\
\multicolumn{4}{l}{ Catatan : Signifikan pada $\alpha$} & critical value 5\%
\end{tabular}

Berdasarkan tabel regresi persamaan penyerapan tenaga kerja diatas menunjukan hasil nilai koefisien determinasi ( $\mathrm{R}$ square) sebesar 0.8935 yang berarti bahwa variabel dalam persamaan ini investasi industri manufaktur, impor dan pertumbuhan ekonomi mempengaruhi penyerapan tenaga kerja industri manufaktur sebesar 89,35\% sedangkan sisanya $10,65 \%$ dijelaskan oleh variabel-variabel lain diluar model

Berdasarkan hasil perhitungan statistik dapat diketahui nilai koefisien tiap-tiap variabel dari persamaan simultan sehingga dapat diketahui hubungan dan besarnya pengaruh yang diberikan tiap variabel-variabel. Berdasarkan hasil regresi data dengan menggunakan metode TSLS (Two-Stage Least Squares). Pembahasan terhadap hasil estimasi akan diuraikan sebagai berikut: 
Faktor-Faktor Yang Mempengaruhi Investasi Sektor Industri Manufaktur Di Indonesia

Pengaruh Suku Bunga Terhadap Investasi Industri Manufaktur Di Indonesia

Variabel suku bunga tidak berpengaruh secara signifikan terhadap investasi industri manufaktur di Indonesia, Hal ini tidak sesuai teori mengacu pada teori pertumbuhan inklusif yang menyebutkan bahwa faktor yang mempengaruhi investasi berdasarkan kebijakan moneter yaitu suku bunga dan juga mengacu pada teori Klasik menyatakan bahwa keputusan apakah suatu investasi akan dilakukan atau tidak tergantung dari tingkat suku bunga yang merupakan biaya dari penggunaan dana (Nopirin, 1992).

Berdasarkan nilai t-statistik suku bunga mempunyai angka yang tidak signifikan diatas nilai probabilita signifikan $0,05(\alpha=5 \%)$ yaitu sebesar 0.4425 yang berarti bahwa variabel suku bunga berpengaruh tidak signifikan terhadap investasi industri manufaktur di Indonesia.

Pengaruh Nilai Tukar terhadap Investasi Industri Manufaktur di Indonesia

Variabel nilai tukar berpengaruh signifikan terhadap terhadap investasi industri manufaktur di Indonesia, hal ini berdasarkan sesuai dengan t-satatistik nilai tukar $\mathrm{Rp} / \mathrm{US} \$$ mempunyai angka yang signifikan dibawah nilai probabilita signifikan 0,05 ( $\alpha$ $=5 \%$ ) yaitu sebesar 0.0167 yang berarti bahwa variabel nilai tukar berpengaruh signifikan terhadap investasi industri manufaktur di Indonesia,

Koefisien hasil regresi nilai tukar rupiah diketahui nilai regresinya sebesar 69,8 nilai ini mempunyai arti bahwa apabila variabel lain dianggap tetap maka kenaikan nilai tukar rupiah terhadap Dollar AS sebesar US\$ 1, maka akan menyebabkan kenaikan investasi industri manufaktur sebesar Rp 69,8 milyar. Secara teoritis dampak perubahan nilai tukar dengan investasi uncertainly (tidak pasti). Menurut sukirno pengaruh tingkat nilai tukar yang berubah pada pada investasi dapat langsung lewat beberapa saluran, perubahan nilai tukar tersebut berpengaruh pada dua saluran, sisi permintaan dan sisi penawaran domestik. Dalam jangka pendek, penurunan nilai tukar akan mengurangi investasi melalui pengaruh negatifnya pada absorbs domestic, karena penurunan nilai tukar ini akan menyebabkan nilai riil asset masyarakat yang disebabkan kenaikan tingkat harga-harga secara umum dan selanjutnya akan menurunkan permintaan domestic masyarakat. Gejala diatas pada tingkat perusahaan akan direspon pada pengeluaran/alokasi modal pada investasi.

Pada sisi penawaran, pengaruh aspek pengalihan pengeluaran akan merubah tingkat nilai tukar pada investasi relatif tidak menentu. Penurunan nilai tukar mata uang domestik akan menaikkan produk-produk impor yang diukur dengan mata uang domestik dan demikian akan meningkatkan harga barang-barang yang diperdagangkan/barang-barang ekspor relatif terhadap barang-barang yang tidak diperdagangkan, sehingga didapatkan kenyataan nilai tukar mata uang domestik akan mendorong ekspansi investasi barang-barang perdagangan tersebut.

Pengaruh PTK Industri Manufaktur terhadap Investasi Industri Manufaktur di Indonesia

Variabel PTK industri manufaktur menunjukan adanya pengaruh secara signifikan terhadap investasi industri manufaktur di Indonesia, sesuai dengan t-statistik PTK industri manufaktur yang mempunyai angka yang sangat signifikan dibawah nilai probabilita signifikan $0,05(\alpha=5 \%)$ yaitu sebesar $0.0007<0,05$ yang berarti bahwa variabel PTK Industri Manufaktur berpengaruh signifikan terhadap investasi industri manufaktur di Indonesia.

Nilai koefisien regresi PTK industri manufaktur sebesar 0.12 nilai ini mempunyai arti bahwa apabila variabel lain dianggap tetap, maka kenaikan PTK industri 20 
manufaktur sebesar 1 juta orang, maka akan menyebabkan kenaikan nilai investasi industri manufaktur sebesar Rp. 0,12, Hal ini sesuai dengan pendapat Sukirno (2006) salah satu faktor penting yang dipertimbangkan untuk faktor yang mempengaruhi investasi adalah nilai pendapatan nasional yang dicapai, dalam kebanyakan analisa mengenai pendapatan nasional pada umumnya variabel investasi yang dilakukan pengusaha berbentuk investasi autonomi (besaran/nilai tertentu investasi yang selalu sama pada berbagai tingkat pendapatan nasional). Tetapi adakalanya tingkat pendapatan nasional sangat besar pengaruhnya pada tingkat investasi.

Sektor industri merupakan sektor yang sangat berperan dalam pembangunan ekonomi karena dapat meningkatkan pertumbuhan ekonomi. Sektor industri juga berperan sebagai faktor produktif dalam memaksimalkan pembangunan. Perkembangan sektor industri tidak hanya ditandai dengan semakin meningkatnya volume produksi, tetapi dengan semakin beragamnya jenis produk yang dihasilkan.

\section{Pengaruh Investasi Sektor Industri Manufaktur Terhadap pertumbuhan ekonomi Sektor Industri Manufaktur di Indonesia}

Variabel investasi sektor industri manufaktur berpengaruh signifikan terhadap PTE industri manufaktur, hal ini sesuai dengan nilai t-statistik pada uji $t$ yang menunjukkan bahwa investasi industri manufaktur yang mempunyai angka yang signifikan dibawah nilai probabilita signifikan $0,05(\alpha=5 \%)$ yaitu sebesar 0.0371 yang berarti bahwa variabel Investasi Industri Manufaktur berpengaruh signifikan terhadap PTE industri manufaktur di Indonesia.

Hasil ini sesuai dengan teori ekonomi yang menyebutkan bahwa salah satu faktor yang mempengaruhi pertumbuhan ekonomi adalah investasi. Salah satu komponen perekonomian dalam pembangunan suatu wilayah adalah investasi yang diperlukan untuk menunjang pertumbuhan ekonomi dan meningkatkan kesejahteraan.

Pertumbuhan investasi dapat dilihat dari pertumbuhan ekonomi yang diukur melalui PDB nya. Investasi tersebut digunakan sebagai salah satu komponenpembangunan perekonomian suatu wilayah karena melalui investasi, kapasitas produksi dapat ditingkatkan yang kemudian mampu meningkatkan output, yang akhirnya juga akan meningkatkan pertumbuhan ekonomi suatu wilayah. Penting untuk untuk melihat potensi dari pengaruh investasi sektor industri manufaktur sebagai salah satu sektor unggulan Indonesia. Tujuan dari melihat kondisi investasi ini ditujukan untuk melihat perkembangan investasi sektor industri manufaktur dari tahun-tahun sebelumnya sampai dengan sekarang. Sedangkan pengaruh investasi dimaksudkan untuk melihat seberapa besar pengaruh dari adanya investasi pada sektor industri manufaktur terhadap perekonomian.

\section{Pengaruh Investasi Sektor Industri Manufaktur Terhadap Penyerapan Tenaga Kerja Sektor Industri Manufaktur di Indonesia}

Perkembangan investasi sektor industri manufaktur di Indonesia pada tahun pengamatan yaitu tahun 2001-2015 cendurung fluktuasif. Berdasarkan Undang-Undang Republik Indonesia nomor 25 tahun 2007 tentang penanaman yang salah satu tujuannya adalah untuk menciptakan lapangan pekerjaan. Dalam Undang-Undang Republik Indonesia nomor 25 tahun 2007 pada pasal 10 dan pasal 13, pada pasal 10 ayat (1) yang isinya Perusahaan penanaman modal dalam memenuhi kebutuhan tenaga kerja harus mengutamakan tenaga kerja warga negara Indonesia dan pasal 13 ayat (2) pemerintah melakukan pembinaan dan pengembangan usaha mikro, kecil, menengah, dan koperasi melalui program kemitraan, peningkatan daya saing, pemberian dorongan inovasi dan perluasan pasar, serta penyebaran informasi yang seluas-luasnya. 
Berdasarkan hasil uji t diperoleh keterangan bahwa variabel investasi berpengaruh positif terhadap penyerapan tenaga kerja sektor industri secara signifikan, Variabel investasi industri manufaktur mempunyai angka yang signifikan dibawah nilai probabilita signifikan $0,05(\alpha=5 \%)$ yaitu sebesar 0.0449 yang berarti bahwa variabel investasi industri manufaktur berpengaruh signifikan terhadap penyerapan tenaga kerja industri manufaktur di Indonesia.

Dengan adanya hasil tersebut yaitu adanya pengaruh investasi terhadap penyerapan tenaga kerja sektor industri secara signifikan tersebut sesuai dengan teori bahwa "kegiatan investasi memungkinkan masyarakat terus menerus meningkatkan pendapatan nasional dan kesempatan kerja, meningkatkan pendapatan nasional dan meningkatkan taraf kemakmuran masyarakat" (Sukirno, 2000). teori tersebut sesuai dengan data yang diperoleh mengenai investasi naik maka penyerapan tenaga kerja sektor industri mengalami kenaikan.

\section{KESIMPULAN DAN SARAN}

\section{Kesimpulan}

1. Investasi industri manufaktur secara simultan dipengaruhi oleh suku bunga (SB), nilai tukar (NT) dan penyerapan tenaga kerja industri manufaktur (PTE), secara parsial dipengaruhi oleh nilai tukar (NT) dengan angka yang signifikan dibawah nilai probabilita signifikan $\alpha=5 \%$ yaitu sebesar 0.0167 dan pertumbuhan ekonomi industri manufaktur (PTE) dengan nilai probabilita sebesar 0.0007 .

2. Investasi industri manufaktur (INV) mempunyai pengaruh yang signifikan terhadap pertumbuhan ekonomi industri manufaktur dengan angka yang signifikan dibawah nilai probabilita signifikan $\alpha=5 \%$ yaitu sebesar 0.0371 .

3. Investasi industri manufaktur (INV) mempunyai pengaruh yang signifikan terhadap pertumbuhan ekonomi industri manufaktur dengan angka yang signifikan dibawah nilai probabilita signifikan $\alpha=5 \%$ yaitu sebesar 0.0449 .

\section{Saran}

1. Untuk menarik investasi yang nantinya akan mampu mendorong perbaikan kinerja sektor industri maka pemerintah daerah dapat melakukan perbaikan tata kelola ekonomi dari sisi barang publik. Barang publik tersebut tidak semata-mata hanya disediakan namun diperlukan perawatan agar manfaat yang dihasilkan oleh barang publik tersebut tidak semakin berkurang di kemudian hari. Ketika barang publik tersedia maka kegiatan ekonomi akan efisien dan mendorong kegiatan investasi, baik investasi dari dalam negeri ataupun luar negeri

2. Untuk mendayagunakan tenaga kerja yang memiliki keterampilan rendah (lowskill), pemerintah daerah dapat melakukan diversifikasi produk sektor industri pengolahan dengan cara membuat unit pengembangan aktivitas bisnis yang mengarah pada industri padat karya yang nantinya akan mampu menampung tenaga kerja yang berketrampilan rendah tersebut.

\section{DAFTAR PUSTAKA}

Ariefianto, Doddy. 2012. Ekonometrika. Penerbit Erlangga. Jakarta.

Arief, Sritua. 1993. Metodologi Penelitian Ekonomi. Penerbit Universitas (UIPress). Jakarta.

Arsyad, Lincoln. 2010. Ekonomi Pembangunan, Edisi 5. UPP STIM YKPN

Yogyakarta. Yogyakarta. 
Asmara, Alla, Dkk. 2013.Faktor - Faktor yang Memengaruhi Perkembangan Investasi pada Industri Tekstil dan Produk Tekstil (TPT) Indonesia. Departemen Ekonomi, Fakultas Ekonomi dan Manajemen Institul Pertanian Bogor. Jurnal Volume 12 No 22013

Badan Koordinasi Penanaman Modal. 2015. Realisasi Modal PMDN dan Investasi PMA Triwulan IV dan Januari-Desember Tahun 2015.

Badan Pusat Statistik, 2005.Laporan Perekonomian Indonesia, Jakarta. , 2001. Statistik Indonesia, Jakarta.

Boediono. 1999. Teori Pertumbuhan Ekonomi. BPFE-Yogyakarta. Yogyakarta.

Dewi, Diah A. 2010. Deindustrialisasi di Indonesia 1983 - 2008 : Sebuah Pendekatan Kaldorian. Thesis. Sekolah Pasca Sarjana Institut Pertanian Bogor. Bogor.

Djojohadikusumo, Sumitro. 1994. Perkembangan Pemikiran Ekonomi : Dasar Teori Pertumbuhan dan Ekonomi Pembangunan. Penerbit Gramedia. Jakarta.

Dumairy. 2011. Matematika Terapan Untuk Bisnis dan Ekonomi. Cetakan Ketiga. BPFE-Yogyakarta. Yogyakarta.

Dumairy. 1996. Perekonomian Indonesia, Cetakan Lima. Penerbit Erlangga. Jakarta

Fikriah dan Wulandari, Meta. 2015. Analisis Pengaruh Investasi Infrastruktur Publik Terhadap Pertumbuhan Ekonomi di Aceh. Jurnal Ekonomi Dan Kebijakan Publik Volume 2 Nomor 1, Mei 2015 ISSN. 2442-7411. Fakultas Ekonomi Universitas Syiah Kuala. Aceh.

Gujarati, Damodar. 2003. Ekonometrika Dasar. (Edisi Alih Bahasa Terjemahan). Erlangga .Jakarta.

Gujarati, D. N. and D.C. Porter. 2009. Basic Econometrics, Fifth Edition. New York: McGraw-Hill.

2012. Dasar-dasar Ekonometrika. Diterjemahkan oleh Raden Carlos Mangunsong. Edisi 5. Penerbit Salemba Empat. Jakarta.

Jonaidi, Arius. 2012. Analisis Pertumbuhan Ekonomi Dan Kemiskinan Di Indonesia. Jurnal Kajian Ekonomi Volume 1, Nomor 1, April 2012.

Junaidi, J. (2014). Analisis Hubungan Deret Waktu untuk Peramalan. Jambi. Fakultas Ekonomi dan Bisnis Universitas Jambi

Junaidi, J., Zulfanetti,Z. (2016). Analisis Kondisi dan Proyeksi Ketenagakerjaan di Provinsi Jambi. Jurnal Perspektif Pembiayaan dan Pembangunan Daerah, 3(3), 141-150.

Kementerian Keuangan Republik Indonesia, 2011. Data Pokok APBN 2005-2011 Indonesia.

Kementerian Perindustrian Republik Indonesia, 2014. Laporan Kinerja Kementerian Perindustrian Republik Indonesia. Indonesia.

2015. Laporan Kinerja Kementerian Perindustrian Republik

Nur, Choirunnisa. 2014. Analisis Tingkat Investasi Terhadap Pertumbuhan Sektor Industri Pengolahan (Studi Pada Kawasan Gerbangkertasusila Tahun 2006-2012). Jurnal Ilmu Ekonomi. Universitas Brawijaya. Malang.

Pujoalwanto, Basuki. 2013. Perekonomian Indonesia. Graha Ilmu. Yogyakarta.

Putra, Gema Setya Anggara. 2012 Analisis Peranan Dan Dampak Investasi Sektor Industri Pengolahan Terhadap Perekonomian Indonesia. Skripsi. Institut Pertanian Bogor. Bogor.

Sukirno, Sadono. 2000, Makroekonomi Modern. PT. Raja Grafindo. Jakarta 
2011, Makro Ekonomi Teori Pengantar, Edisi Ketiga. PT Raja Grafindo Persada. Jakarta.

Sulaksono, Agus. 2015. Pengaruh Investasi Dan Tenaga Kerja Terhadap PDB Sektor Pertambangan Di Indonesia. Jurnal Ekonomi Bisnis Volume 20 No.1, April 2015. Fakultas Ekonomi, Universitas Gunadarma. Jawa Barat.

Sulistiawati, Rini. 2012. Pengaruh Investasi terhadap Pertumbuhan Ekonomi dan Penyerapan Tenaga Kerja Serta Kesejahteraan Masyarakat di Provinsi di Indonesia. Jurnal Ekonomi Bisnis dan Kewirausahaan 2012, Vol. 3, No. 1, 29-50. Jurusan Ilmu Ekonomi Fakultas Ekonomi Universitas Tanjungpura, Pontianak.

Syaparuddin dan Dahmiri. 2010. Model Permintaan Hutang Luar Negeri Pemerintah Dan Dampaknya Terhadap Kemiskinan Di Indonesia. Volume 12, Nomor 1, Hal. 9-24. Fakultas Ekonomi, Universitas Jambi. Jambi.

Tambunan TTH. 2001. Industri di Negara Sedang Berkembang.Penerbit Ghalia Indonesia, Jakarta.

Tambunan, Tulus T.H. 2011. Perekonomian Indonesia : Kajian Teoritis dan Analisis Empiris. Ghalia Indonesia, Bogor.

Todaro, Michael and Smith,C Stephen. 2006. Pembangunan Ekonomi Edisi Kesembilan Jilid 2. PT Gelora Aksara Pratama. Jakarta.

Erlanggga, Jakarta.

Tri Mulyani Setyowati. 2015. Analisis Pengaruh Investasi Sektor Transportasi Terhadap Pertumbuhan Ekonomi Indonesia Tahun 2004 - 2013. Jurnal Manajemen Bisnis Transportasi Dan Logistik, Vol.1 No 3 Mei 2015. STMT Trisakti

Yuliadi, Imamudin. 2008. Analisis Impor Indonesia: Pendekatan Persamaan Simultan. Jurnal Ekonomi dan Studi Pembangunan Volume 9, Nomor 1, April 2008: 89- 104. Fakultas Ekonomi Universitas Muhammadiyah Yogyakarta. Yogyakarta. 